\title{
An Analysis of Adult Education Programme in Lagos State: Implication for Policy Implementation
}

\author{
Saula Ayinla Shamsideen \\ Adeniran Ogunsanya College of Education Otto-Ijanikin, Lagos, Nigeria
}

\begin{abstract}
The research work investigated the analysis of Adult Education Programme in Lagos State: Implication for Policy Implementation. Three null hypotheses were formulated for the study and the instrument that was used for the study was questionnaire. A descriptive survey design was adopted for the study. The sample included 100 respondents randomly selected from adult learners and instructors. Data was analyzed using frequency table, percentage and Chi-square. Based on the results of this study, conclusion was made that constant monitoring and supervision would add value to implementation and Governments are encouraged to pay special attention to Adult Education programme as a channel for lifelong Education.
\end{abstract}

\section{Introduction}

The National Policy on Education provides for Adult and non-formal education as an instrument par excellence for lifelong education [3]. The goals of adult and non-formal education to include providing functional literacy and continuing education for adults and the youths, provide education for different categories of completers of the formal education system to improve their basic knowledge and skills, provide in-service, on-the-job, vocational and professional training for different categories of workers and give adult citizens of the country necessary aesthetics, cultural and civic education for public enlightenment.

Ugwuegbu opined that Adult Education in Nigeria is not just about literacy or remedial education to fill a gap [7]. That it is what is needed and wanted by all as long as they are alive and regardless of previous education. This position is in line with what Nasir said when he said that Adult Education included many of the subjects learned at school for those who never had the opportunity [6]. Dave had had earlier argued that Adult Education aims at providing lifelong Education that prepares the individual for change and creates dynamic frame of mind in the individual [2]. This is because the world is constantly changing in all spheres including technology, communication and industry. Human's craving for learning is this continuous to keep pace with the changes. Bown and Okedara rightly described this urge for continuous learning as 'cradle to grave' [1].

It is hoped that when the individual is equipped through lifelong skills and knowledge, Nigeria's hope for the realization of the millennium development goals that include eradication of extreme poverty and hunger, achieving universal primary education, promoting gender equality and empowering women, reducing child mortality, improving maternal health, combating HIV/Aids, malaria and other diseases ensuring environmental sustainability and developing a global partnership for development would be enhanced [4].

\section{Statement of the Problem}

The main thrust of the paper is to determine the extent of congruence between the policy enunciation and policy implementation as related to Adult Education programme as a channel for lifelong Education in Lagos State, Nigeria. Policy enunciation is one thing, Policy implementation is another. The greatest impact of a programme is achieved when there is a positive correlation between the two important components. The problems paused for investigation here were the policy enunciated, what was obtainable, what was lacking and the challenges. In this regards, the issues of enrolment, gender equity, instructional materials, infrastructure, funding and the curriculum offering were examined.

\subsection{Purpose of the Study}

The main purpose of this study is to determine the extent of congruence between the policy enunciation and policy implementation as related to adult education programme as a channel for lifelong education.

\subsection{Research Questions}

In order to give the research a focus, the following questions were asked:

i. What does the policy on Adult Education as an instrument for lifelong education say?

ii. What is the impact of the programme on the populace?

iii. What have been the problems initiating against the smooth implementation of policy objectives? 
iv. How can these problems be mitigated to enhance policy attainment?

\subsection{Research Hypotheses}

$\mathrm{HO}_{1}$ : There is no significance relationship between adult education instrument for lifelong education and implication for policy implementation $\mathrm{HO}_{2}$ : There is no significance relationship between impact of programme on populace and implication for policy implementation

$\mathrm{HO}_{3}$ : There is no significance relationship between programme objectives and implication for policy implementation.

\subsection{Significance of the Study}

The significance of this study is primarily to establish a number of challenges facing the full implementation of the Adult Education programmes in Lagos State, Nigeria. It will also contribute to the public enlightenment about opportunities provided for enhancing improving and modifying the quantity of education programmes in the state.

\subsection{Limitations of the Study}

Large numbers of the respondents were found all over the nation owing to time constraint but the study was limited to Lagos state.

\section{Research Methodology}

This involved the method and procedures that were followed in carrying out this research, which included the following:

\subsection{Research Design}

The study adopted a descriptive survey research design. The survey research design elicit data of large magnitude at the same time reduce time lag. This accounted for the choice of this design.

\subsection{Population of the Study}

The population of the study consisted of all the Adult learners and instructors across the 20 Local Government Areas in Lagos State.

\subsection{Sample and Sampling Technique}

The sample for the study consisted of 100 Adult learners and instructors across the 20 Local Government Areas in Lagos State.

The random sampling technique was adopted. This was adopted in order to cover all parts of the study area and also to give all units of the population an equal chance of being selected. This technique ruled out bias and created room for credibility, reliability and validity of the study.

\subsection{Instrument for Data Collection}

A self developed questionnaire was used to collect data from the respondents in order to give direct information on the subject under study. This formed the primary source of data. The secondary sources of data included books, journal articles, magazines, newspapers, internet and other publications. All these sources were referenced at the end of the day.

\section{Method of Data Analysis}

The study employed both the descriptive and the inferential statistical methods. In this, the simple percentages and frequency table were used for descriptive purpose while the chi-square statistical analysis was adopted to test the hypothesis in order for inferences to be made.

\section{Results and Discussions}

The data collected through the questionnaire were collated and subjected to statistical test. The percentage distribution method was used to analyse the bio-data and Chi-square Statistical analysis was used to test the hypothesis at 0.05 level of significance. Results and discussion were presented as follows:

Table 1. Gender of respondents

\begin{tabular}{|c|c|c|}
\hline Variables & Frequency & Percentage \\
\hline Male & 61 & 61 \\
\hline Female & 39 & 39 \\
\hline Total & 100 & 100 \\
\hline
\end{tabular}
respondents were male the highest frequency.

Table 2. Qualification of Respondents

\begin{tabular}{|c|c|c|}
\hline Variables & Frequency & Percentage \\
\hline $\begin{array}{c}\text { Senior Secondary } \\
\text { School Cert. }\end{array}$ & 34 & 34 \\
\hline First Degree & 47 & 47 \\
\hline Others & 19 & 19 \\
\hline Total & 100 & 100 \\
\hline
\end{tabular}

From the table above, majority of the respondents were First degree holders. 


\subsection{Testing of Hypotheses}

Hypothesis 1: There is no significance relationship between adult education instruments for lifelong education and implication for policy implementation.

Table 3. Result showing the relationship between adult education instrument and implication for policy implementation

\begin{tabular}{|l|c|c|c|c|c|c|c|l|l|}
\hline Groups & A & D & U & $\begin{array}{l}\text { Tot } \\
\text { al }\end{array}$ & Df & P & $\begin{array}{l}\text { Cal } \\
\mathrm{X}^{2}\end{array}$ & $\begin{array}{l}\text { Tabl } \\
\mathrm{e} \\
\mathrm{X}^{2}\end{array}$ & $\begin{array}{l}\text { Decisi } \\
\text { on }\end{array}$ \\
\hline Adult \\
learners & 4 & 1 & - & 50 & 2 & 0 & 6.1 & 5.99 & Reject \\
& 0 & & & & 0 & & & \\
\cline { 1 - 5 } Instructo & 2 & 2 & 1 & 50 & & 5 & & & \\
rs & 9 & 0 & & & & & & & \\
\hline Total & 8 & 1 & 2 & 100 & & & & & \\
& 0 & 8 & & & & & & & \\
\hline
\end{tabular}

The table above shows that calculated value is greater than the table value, thus null hypothesis is rejected. This implies that adult education aims a providing lifelong education that preparers the individual for change and creates dynamic frame of mind in the individual. In conclusion, adult education instrument has a significant influence on implication for policy implementation.

\section{Hypothesis 2:}

There is no significance relationship between impact of programme on populace and implication for policy implementation.

Table 4. Result showing the relationship between impact of programme on populace and implication for policy

\begin{tabular}{|c|c|c|c|c|c|c|c|c|c|}
\hline Groups & A & $\mathrm{D}$ & $\mathrm{U}$ & $\begin{array}{l}\text { Tot } \\
\text { al }\end{array}$ & $\begin{array}{l}\mathrm{D} \\
\mathrm{f}\end{array}$ & $\mathrm{P}$ & $\begin{array}{l}\text { Cal } \\
X^{2}\end{array}$ & $\begin{array}{l}\text { Tabl } \\
\mathrm{e} \\
\mathrm{X}^{2}\end{array}$ & $\begin{array}{l}\text { Decisi } \\
\text { on }\end{array}$ \\
\hline $\begin{array}{l}\text { Adult } \\
\text { Learners }\end{array}$ & $\begin{array}{l}4 \\
1\end{array}$ & 6 & 3 & 50 & \multirow[t]{3}{*}{2} & \multirow[t]{3}{*}{$\begin{array}{l}0.0 \\
5\end{array}$} & \multirow[t]{3}{*}{$\begin{array}{l}7.2 \\
8\end{array}$} & \multirow[t]{3}{*}{5.99} & \multirow[t]{3}{*}{ Reject } \\
\hline $\begin{array}{l}\text { Instructo } \\
\text { rs }\end{array}$ & $\begin{array}{l}3 \\
5\end{array}$ & $\begin{array}{l}1 \\
5\end{array}$ & - & 50 & & & & & \\
\hline Total & $\begin{array}{l}7 \\
6\end{array}$ & $\begin{array}{l}2 \\
1\end{array}$ & 3 & 100 & & & & & \\
\hline
\end{tabular}

Since the calculated value 7.28 is greater than the tabulated value 5.59, the null hypothesis is rejected. This implies that impact of the programme improves their basic knowledge, skills, vocational and professional trainings for different categories of workers. In conclusion, the impact of programme on populace has significant effect on the implication for policy implementation.

Hypothesis 3:

There is no significance relationship between programme objectives and implication for policy implementation.
Table 4. Result showing the relationship between programme objectives and implication for policy implementation

\begin{tabular}{|c|c|c|c|c|c|c|c|c|c|}
\hline Groups & A & D & $\mathrm{U}$ & $\begin{array}{l}\text { Tot } \\
\text { al }\end{array}$ & $\begin{array}{l}\text { D } \\
\text { f }\end{array}$ & $P$ & $\begin{array}{l}\text { Cal } \\
X^{2}\end{array}$ & $\begin{array}{l}\text { Tabl } \\
\mathrm{e} \\
\mathrm{X}^{2}\end{array}$ & $\begin{array}{l}\text { Decisi } \\
\text { on }\end{array}$ \\
\hline $\begin{array}{l}\text { Adult } \\
\text { Learners }\end{array}$ & $\begin{array}{l}4 \\
2\end{array}$ & 8 & - & 50 & \multirow[t]{3}{*}{2} & $\begin{array}{l}0.0 \\
5\end{array}$ & \multirow[t]{3}{*}{$\begin{array}{l}11.0 \\
8\end{array}$} & \multirow[t]{3}{*}{5.99} & \multirow[t]{3}{*}{ Reject } \\
\hline $\begin{array}{l}\text { Instructo } \\
\text { rs }\end{array}$ & $\begin{array}{l}2 \\
7\end{array}$ & $\begin{array}{l}2 \\
1\end{array}$ & 2 & 50 & & & & & \\
\hline Total & $\begin{array}{l}7 \\
2\end{array}$ & $\begin{array}{l}1 \\
9\end{array}$ & 9 & 100 & & & & & \\
\hline
\end{tabular}

Since the calculated value 11.08 is greater than the tabulated value 5.59, the null hypothesis is rejected. This implies that programme objectives eradicate extreme poverty, hunger and promoting gender equality to ensure environmental sustainability. In conclusion, programme objectives have significant influence on implication for policy implementation.

\section{Conclusion}

In conclusion, while policy statements are usually laudable, the need to harmonize, it with policy implementation cannot be over emphasized for desired impact. Through constant evaluation or review there is likelihood to ensure congruence between the two. (Policy structured and policy Implementation). Constant monitoring and supervision would add value to implementation and Governments are encouraged to pay special attention to Adult Education Programme as a channel for lifelong Education.

\section{Recommendations}

To overcome the limitation of implementation and bring it at par with policy statement the following are recommended:

i. Adequate funding: Since adult education is central to the individual's survival and contribution to the progress of the State and nation; it should be adequately funded by the government. It is worthy of note that the $26 \%$ budgetary allocation to education recommended by UNESCO has never been met.

ii. Available and reliable data is needed for proper planning and implementation. Data on the needs of learners, the number of those out of school, the required classroom and needed instructors.

iii. Change in societal attitude: Society must ascribe value and prestige to this system of learning and appreciate it as needed for lifelong Education.

iv. Counselling Programme: Just as in the formal system of education, counselors should be posted to the learning centres to assists the learners.

v. Policy documents like the NPE and Nigerian Constitutions should be clear to what specific roles the different levels of Governments, 
Federal, State and Local Governments should play in the implementation of specific programmes.

vi. Males should be enlightened more on the importance of these centres in the delivery of lifelong education.

vii. The Government agencies should monitor and supervise the quality of instruction.

\section{References}

[1] Bown, L. and Okedara, L.T., an Introduction to the study of Adult education, Ibadan: University |Press Ltd. 1981.

[2] Dave, R. Lifelong Education and Alcohol, Hamburg: UNESCO, Institute of Education. 1973

[3] Federal republic of Nigeria. National Policy on Education, Abuja Government Printer. 2004

[4] Federal Government of Nigeria, Millennium Development Goals, Nigeria: report, Abuja. 2004.

[5] Haggai, M and Mang, L. 'Supplementing secondary education for poor families', Nigeria Journal of Curriculum Studies, Vol. 10, 2. 2003.

[6] Nosir, P. 'The concept of lifelong education and its implications to school curriculum', Adult Education in Nigeria; Ibadan. The Nigerian National council, Vol. 4. 1979.

[7] Ugwuegbu, L.T. Adult Education: Principles and Programme Design, Awka, Ekuma Co. Ltd. 2003. 